\author{
Aleksandra Wierzchowska \\ https://orcid.org/0000-0002-4774-9487 \\ Instytut Pamięci Narodowej
}

\title{
Kongres futurologiczny. Eurocon 1976 w Poznaniu
}

\begin{abstract}
Abstrakt: Tekst ukazuje przebieg i znaczenie III Europejskiego Kongresu Science Fiction (Euroconu), powody zorganizowania międzynarodowego zjazdu twórców i miłośników fantastyki w kraju komunistycznym oraz działania podejmowane przez Służbę Bezpieczeństwa w związku z przyjazdem gości zagranicznych.
\end{abstract}

Słowa kluczowe: fandom, science fiction, Związek Literatów Polskich (ZLP), Stanisław Lem, Służba Bezpieczeństwa (SB).

Abstract: The text shows the course and significance of the 3rd European Science Fiction Convention (Eurocon), the reasons for organising an international convention of fantasy authors and enthusiasts in a communist country and the actions taken by the Security Service in connection with the arrival of foreign visitors.

Key w ords: Fandom, science fiction, Union of Polish Writers, Stanisław Lem, Security Service.

Konwenty fantastyki łączą w sobie cechy zlotów fanów, konferencji naukowych i festiwali literackich lub filmowych. Ich historia sięga drugiej połowy lat trzydziestych, gdy w Stanach Zjednoczonych i Wielkiej Brytanii odbyły się lokalne zjazdy miłośników fantastyki ${ }^{1}$ W 1939 r. w Nowym Jorku zorganizowano

\footnotetext{
${ }^{1}$ Pierwszym konwentem science fiction nazywa się zwykle spotkanie fanów z Nowego Jorku i Filadelfii w domu Miltona A. Rothmana w październiku 1936 r. (pierwszy Philcon). Część badaczy uważa, że pierwszym „prawdziwym” konwentem - otwartym wydarzeniem
} 
pierwszą edycję Worldconu (The World Science Fiction Convention), który co roku miał gościć w innym miejscu i gromadzić fanów nie tylko z USA².

Podobny charakter ma Eurocon, który po raz pierwszy odbył się w lipcu 1972 r. w Trieście. Wzięli w nim udział także przedstawiciele krajów bloku wschodniego: PRL, Węgier, Rumunii, Czechosłowacji i Związku Sowieckiego. Eurocon - a właściwie I Europejski Kongres Science Fiction - adresowany był głównie do profesjonalnych twórców, co spotkało się z krytyką części fanów, przyzwyczajonych do spontanicznej atmosfery lokalnych konwentów. W Trieście powołano do życia Europejski Komitet Science Fiction (ESFC, obecnie Europejskie Stowarzyszenie Science Fiction - ESFS), który miał odtąd czuwać nad przebiegiem kolejnych Euroconów oraz przyznawać nagrody pisarzom, wydawcom, tłumaczom i artystom zasłużonym dla rozwoju fantastyki naukowej. Początkowo planowano, że kongres będzie się odbywać w odstępie dwuletnim, a podczas obrad wybrany zostanie kraj organizujący następną edycję. II Eurocon miał miejsce w lipcu 1974 r. w Grenoble ${ }^{3}$, a dwa lata później zagościł w Poznaniu.

Celem artykułu jest wyjaśnienie, w jaki sposób ogólnoeuropejski konwent zawędrował za żelazną kurtynę, ukazanie jego przebiegu i znaczenia, a także działań podejmowanych przez Służbę Bezpieczeństwa (SB) w związku z przyjazdem licznej grupy twórców zagranicznych.

\section{Odyseja kosmiczna}

Od końca lat pięćdziesiątych Stany Zjednoczone i Związek Sowiecki konkurowały ze sobą także w przestrzeni pozaziemskiej. Znaczenie tej rywalizacji dalece wykraczało poza korzyści militarne, gospodarcze czy naukowe - sukcesy miały też dowodzić wyższości ustroju politycznego ${ }^{4}$. Początkowo w „kosmicznym

z ustalonym wcześniej programem - był zjazd brytyjskich działaczy Science Fiction League, który odbył się w styczniu 1937 r. w Leeds; uczestniczył w nim m.in. Arthur C. Clarke. Więcej na ten temat zob. The first convention (1937) oraz The first ever convention - artykuły opublikowane w serwisie flawol.org.uk (dostęp: 13 VII 2020).

${ }^{2}$ W tamtych dekadach Worldcon rzadko opuszczał granice USA. Pierwsza edycja zagraniczna odbyła się w 1948 r. w Kanadzie, kolejna - w 1957 r. w Wielkiej Brytanii. Do Europy kontynentalnej Worldcon zawędrował dopiero w 1970 r., goszcząc w Heidelbergu (RFN).

${ }^{3}$ II Eurocon miał się odbyć w Brukseli, ale po trudnościach związanych z organizacja własnego konwentu lokalne kluby wycofały się z przedsięwzięcia. Eurocon II cancelled, „Checkpoint”, 27 X 1973, nr 42. Ostatecznie zadania podją się fandom francuski - II Eurocon połaczono z pierwszą edycją narodowego konwentu Francji w Grenoble (8-13 VII 1974 r.), Bruksela została zaś gospodarzem IV Euroconu w 1978 r.

${ }^{4}$ Więcej na ten temat zob. H. Wilk, Od Sputnika do selenonautów. Kosmiczny wyścig w świetle oficjalnej propagandy PRL (1957-1969), w: Yesterday. Studia z historii najnowszej. Ksiega dedykowana prof. Jerzemu Eislerowi w 65. rocznice urodzin, red. J. Olaszek, Warszawa 2017, s. $375-389$. 
wyścigu" prowadził ZSRS, który w 1957 r. umieścił na orbicie sztucznego satelitę, a dwa lata później - pierwszego człowieka, Jurija Gagarina. Propaganda komunistyczna głosiła, że tego dnia „otwarła się [...] era podboju kosmosu, opanowania przyrody w zasięgu systemu słonecznego. [...] Sprawiła to wyższość socjalizmu nad kapitalizmem"5. Z upływem lat Związek Sowiecki tracił jednak przewagę, a w lipcu 1969 r. to Amerykanie jako pierwsi wylądowali na Srebrnym Globie ${ }^{6}$. Wydarzenie było transmitowane na żywo przez polska telewizję i zgromadziło przed odbiornikami miliony widzów.

W następnej dekadzie tempo rywalizacji zmalało. Zauważano odprężenie w relacjach amerykańsko-sowieckich. W maju 1972 r., podczas wizyty prezydenta Richarda Nixona w Związku Sowieckim, ogłoszono plan wspólnego lotu załogowego USA i ZSRS. Apollo 18 i Sojuz 19 wystartowały 15 VII 1975 r., a dwa dni później spotkały się i połączyły na ponad 43 godziny. Dowódcy załóg uścisnęli sobie dłonie, wymieniono prezenty, rozpoczęły się wspólne prace naukowe. W trakcie misji odbyły się też transmisje telewizyjne i konferencja prasowa.

Kierujący misja Sojuza Aleksiej Leonow 10 lat wcześniej zapisał się w historii jako pierwszy kosmonauta, który wyszedł na spacer w przestrzeni pozaziemskiej. „Czułem się jak mewa z rozpostartymi skrzydłami, szybująca wysoko nad Ziemia”" - wspominał później. Został też pierwszym człowiekiem, który na orbicie... rysował - podczas swojego lotu naszkicował wschód Słońca widziany z iluminatora Woschodu 2. Już w młodości wykazywał zainteresowania artystyczne, ale nie został przyjęty do Akademii Sztuk Pięknych. Zamiłowanie do sztuk plastycznych rozwinął później, malując obrazy o tematyce kosmicznej. Jego twórczość była prezentowana na różnych wystawach, a jedna z nich odbyła się w Poznaniu - właśnie przy okazji Euroconu. Leonow opowiadał zresztą w wywiadzie, że jedno z jego „dzieł” z dzieciństwa przedstawiało pojazd kosmiczny na Księżycu, a kiedy przygotowywał się do pierwszego lotu i chciał zrozumieć, jak czuje się człowiek w przestrzeni kosmicznej, odpowiedzi szukał m.in. w fantastyce naukowej.

Eksploracja kosmosu, o której można było usłyszeć w radiu czy przeczytać w prasie codziennej, budziła fascynację i poczucie, że przyszłość dzieje się właśnie teraz, że nawet najbardziej fantastyczne wizje moga się urzeczywistnić, a postęp technologiczny przyniesie rozwiązanie wielu aktualnych problemów (chociaż spowoduje nowe). Tworzyło to podatny grunt dla rozwoju literatury

${ }^{5}$ [Komentarz], „Trybuna Ludu”, 14 IV 1961, s. 1, cyt. za: H. Wilk, op. cit., s. 379.

${ }^{6}$ Wcześniej dotarła tam jednak sowiecka sonda, która rozbiła się o powierzchnię Księżyca. Model Łuny 2 (pozbawiony silników oraz większości elementów elektronicznych) był prezentowany na wystawie objazdowej, która miała ukazać wyższość sowieckiej technologii. CIA zdołała „wypożyczyć” model do zbadania podczas transportu. Zob. https://www.cia.gov/ readingroom/docs/DOC_0000609203.pdf (dostęp: 15 IX 2021).

${ }^{7}$ W. Brzeziński, Powrót do gwiazd, https://www.tygodnikpowszechny.pl/powrot-do-gwiazd-160689 (dostęp: 21 VIII 2020). 
fantastycznonaukowej, która z kolei jeszcze bardziej rozbudzała ciekawość świata. Tadeusz Zysk zwraca uwagę, że „dzięki takim młodzieżówkom SF [...] wychowano pokolenie Amerykanów, którzy polecieli na Księżyc. Takie książki przygotowują rzesze dorosłych miłośników fantastyki, nauki, wywołuja pragnienie wiedzy"8. Wielu autorów science fiction (SF) zajmowało się też popularyzacja nauki i techniki; w Polsce byli to m.in. astronom Krzysztof Borun, informatyk Konrad Fiałkowski czy fizyk Janusz A. Zajdel. Ten ostatni, podobnie jak kilku cenionych w latach siedemdziesiatych i osiemdziesiątych polskich pisarzy SF, debiutował w „Młodym Techniku”, gdzie publikowano opowiadania fantastycznonaukowe, by kształtować kreatywność młodych czytelników. Od poczatku lat siedemdziesiątych opowiadania science fiction prezentował też popularnonaukowy miesięcznik „Problemy”, w którym działem literackim (powszechnie znanym jako „żółte kartki”) kierował Konrad Fiałkowski ${ }^{9}$.

\section{Brama do gwiazd}

Zjawiskiem charakterystycznym dla science fiction jest dążenie miłośników tej literatury do wzajemnych spotkań i korespondencji, poznania na żywo ulubionych autorów czy próbowania własnych sił w pisaniu. W krajach bloku wschodniego środowiska fanowskie z oczywistych względów nie mogły się rozwijać równie szybko i swobodnie co fandom w Stanach Zjednoczonych lub Europie Zachodniej, ale wraz z rosnąca popularnością fantastyki pojawiały się też mniej lub bardziej formalne zrzeszenia. Pierwsze grupy fanów funkcjonowały często w ramach klubów młodzieżowych, organizacji studenckich lub kół zainteresowań przy bibliotekach i domach kultury. W demoludach jedna z najstarszych organizacji skupiających pasjonatów science fiction i nauki był bułgarski klub „Przyjaciele przyszłości”, założony w 1962 r. w Sofii. Siedem lat później powstały stowarzyszenia miłośników fantastyki w Bukareszcie (od 1973 r. pod nazwa Solaris) i w Pradze (Klub Juliusza Verne'a). W Polsce pierwsza organizacja fanowska to Klub Miłośników Astronautyki, Astronomii i Fantastyki „Astron” z Brzegu (wówczas jeszcze pod nazwą „Saturn”), założony w 1974 r., jednak faktyczny rozwój fandomu datuje się od powstania Ogólnopolskiego Klubu Miłośników Fantastyki i Science Fiction w 1976 r.

Jednocześnie kształtował się ruch międzynarodowy, który przekraczał granice sojuszy polityczno-militarnych. W 1970 r. w Tokio odbyło się Międzynarodowe Sympozjum Pisarzy Science Fiction, na które zaproszono m.in.

\footnotetext{
${ }^{8}$ W. Sedeńko, Pejzaż z gwiazdami, Stawiguda 2018, s. 248.

${ }^{9}$ Fiałkowski wspominał, że wprowadzenie science fiction na łamy pisma musiał wywalczyć, bo redaktor naczelny był „mocno nieprzekonany do fantastyki naukowej”. M. Żelkowski, Lista nieobecnych. Rozmowy z pisarzami, Stawiguda 2014, s. 84.
} 
Stanisława Lema, ostatecznie jednak blok wschodni reprezentowali tylko twórcy z ZSRS. Organizator sympozjum wspominał, że wielu zachodnich (także europejskich!) pisarzy dopiero wówczas dowiedziało się, że w Związku Sowieckim istnieje literatura science fiction ${ }^{10}$. Mimo to autorzy i wydawcy fantastyki naukowej, działajac w oficjalnych zrzeszeniach pisarzy, redagujac antologie czy kontaktując się w sprawie tłumaczeń, stopniowo nawiązywali relacje ze swoimi zagranicznymi kolegami. W taką działalność zaangażowani byli m.in. brytyjski pisarz i krytyk Brian Aldiss, szwedzki tłumacz i pisarz Sam J. Lundwall, a w krajach komunistycznych - Péter Kuczka (węgierski wydawca i pisarz, redaktor naczelny pisma „Galaktika”), Jeremiej Parnow (literat, uczestnik wspomnianego wyżej sympozjum w Tokio) i Czesław Chruszczewski, prezes wielkopolskiego oddziału Związku Literatów Polskich (ZLP).

Chruszczewski (1922-1982), dziennikarz, pisarz i scenarzysta, w czasie II wojny światowej zaangażował się w pracę konspiracyjną w organizacji Polscy Socjaliści oraz Socjalistycznej Organizacji Bojowej (SOB) ${ }^{11}$. Po wojnie działał w ruchu socjalistycznym (Organizacja Młodzieży Towarzystwa Uniwersytetu Robotniczego i PPS), a po „zjednoczeniu” - w PZPR. W 1950 r. zamieszkał w Poznaniu, gdzie objął kierownictwo Wydziału Propagandy Komitetu Wojewódzkiego (KW) PZPR. Wkrótce potem rozpoczął karierę dziennikarska w „Expressie Poznańskim” oraz Radiu Poznań: prowadził audycje o literaturze, programy publicystyczne, historyczne i satyryczne, a także kabarety literackie. Pisał też opowiadania i powieści fantastycznonaukowe (zadebiutował w 1960 r.) - i to właśnie jako autor science fiction został zapamiętany. Jego twórczość nie cieszyła się jednak uznaniem krytyków ani miłośników gatunku, charakteryzowały ją „niekonsekwencje motywacyjne, uproszczony rysunek bohatera, schematyzm epizodycznej fabuły"12. Często podawana jest informacja, że na pierwszym Euroconie Chruszczewski otrzymał nagrodę specjalna za całokształt twórczości literackiej, ale jego nazwisko nie widnieje w żadnym wykazie laureatów. Mogło to być inne, mniej oficjalne wyróżnienie, którego nie uwzględniono w sprawozdaniach.

Choć nie był cenionym pisarzem, okazał się dobrym animatorem życia fanowskiego. Szybko nawiązywał kontakty z zagranicznymi autorami i wydawcami fantastyki, stając się niemal „etatowym przedstawicielem fandomu SF"13. W 1971 r. w Budapeszcie odbył się zjazd pisarzy science fiction z krajów

${ }^{10}$ Wywiad z Komatsu Sakyô, https://www.depauw.edu/sfs/backissues/88/komatsu\%20interview. htm (dostęp: 17 XI 2020).

${ }^{11}$ Socjalistyczna Organizacja Bojowa (SOB) została utworzona w 1943 r. przez środowisko Związku Niezależnej Młodzieży Socjalistycznej; przynależność Chruszczewskiego do SOB i organizacji Polscy Socjaliści mogła mieć wpływ na jego rolę i środowiskowe relacje w ZLP.

12 A. Niewiadowski, A. Smuszkiewicz, Leksykon polskiej literatury fantastycznonaukowej, Poznań 1990, s. 52.

${ }^{13}$ W. Bukato, Sceny z życia smoków fandomu, „Miesięcznik Śląskiego Klubu Fantastyki” 2001, nr 142, s. 17. 
komunistycznych (Pierwsze Konsultatywne Spotkanie Pisarzy SF), jeszcze bez reprezentantów PRL. Gdy jesienia 1972 r., już po pierwszym Euroconie, $\mathrm{w}$ środowisku pisarzy bloku wschodniego podjęto prace nad kontynuacja węgierskiego kongresu, „wspominaliśmy o Moskwie, Pradze, Bukareszcie, Berlinie i Sofii, ale nie mówiliśmy o Warszawie, [...] nazwa Poznań nawet nie przyszła nam na myśl" ${ }^{14}$ - opowiadał Péter Kuczka. Jednak zaangażowanie Chruszczewskiego oraz przychylność lokalnych władz (zrozumiała, zważywszy na jego polityczne umocowanie) i ZLP musiały odegrać istotną rolę w decyzji o organizacji kolejnego zjazdu właśnie w stolicy Wielkopolski.

Międzynarodowe Spotkanie Pisarzy Twórców Literatury Fantastyczno-Naukowej odbyło się w Poznaniu w dniach 11-14 IX 1973 r. Uczestniczyły w nim delegacje krajowych związów pisarzy z Bułgarii, Czechosłowacji, NRD, Rumunii, Węgier i ZSRS. Czy miała to być konkurencja dla Euroconów? Wydaje się, że chodziło przede wszystkim o stworzenie wspólnego bloku promującego fantastykę z krajów komunistycznych, a zwłaszcza utwory o odpowiednim przesłaniu ideowym. W deklaracji przyjętej na zakończenie zjazdu wyrażono przekonanie, że „literatura fantastyczno-naukowa o wysokich walorach artystycznych i społecznych służy ideałom pokoju i rozwoju socjalizmu”"15. Oczywiście można te słowa traktować jako daninę dla „czynników oficjalnych", ale większość utworów drukowanych wówczas w demoludach to wciąż jeszcze tzw. literatura cudownego wynalazku, skupiająca się na przewidywaniu rozwoju technologicznego i jego konsekwencji (zwykle pozytywnych) dla ludzkości. Jednocześnie obecny na zjeździe Vladimir Colin (Rumunia) apelował: „Jeśli nawet zachodnia SF stworzyła dzieła czysto reakcyjne, nie możemy pominąć $[. .$.$] pisarzy szczerze wyrażających opinie lewicy, których$ stanowiska sa bardzo bliskie naszym [...] sa postaciami reprezentatywnymi dla szlachetnego prądu ideowego, który przepływa ponad granicami" ${ }^{16}$. Profesor Julij Kagarlicki (ZSRS) zauważył, że „zacieśniająca się stale współpraca pomiędzy postępowymi pisarzami Wschodu i Zachodu czynią stanowisko izolacjonistyczne bezsensownym"17.

\section{Kroniki marsjańskie}

Współpraca, o której mówił Kagarlicki, była widoczna - pisarze zza żelaznej kurtyny brali udział w dwóch pierwszych Euroconach i od samego założenia ESFC/ESFS aktywnie uczestniczyli w pracach tej organizacji. Fantastyka

${ }^{14}$ P. Kuczka, Problemy wegierskiej literatury fantastyczno-naukowej, w: Materiaty z Międzynarodowego Spotkania Pisarzy - Twórców Literatury Fantastycznonaukowej, red. J. Kaczmarek, B. Kledzik, Poznań 1974, s. 69.

${ }^{15}$ Materiaty..., s. 116.

16 Ibidem, s. 84.

17 Ibidem, s. 112. 
polska, sowiecka czy węgierska była tłumaczona na zachodnie języki i coraz bardziej dostępna zagranicznym odbiorcom. Zorganizowanie jednej z kolejnych edycji kongresu w kraju komunistycznym wydawało się zatem kwestią czasu, a udany przebieg spotkania pisarzy z września 1973 r. niewątpliwie posłużył jako dobra reklama Poznania i samego Chruszczewskiego. Pisarz mógł liczyć na poparcie władz dla tej inicjatywy: ekipa Edwarda Gierka głosiła hasła budowy drugiej Polski i otwarcia na Zachód; propaganda przedstawiała PRL jako kraj modernizujący się w szybkim tempie i przyjazny gościom zagranicznym. W tamtej dekadzie wielokrotnie wzrosła liczba przyjazdów turystów z krajów kapitalistycznych - z 312,7 tys. w 1971 r. do ponad miliona w 1979 r. ${ }^{18}$ Władze wspierały rozwój turystyki przyjazdowej w celu pozyskania tak potrzebnej zachodniej waluty ${ }^{19}$, a także zaprezentowania sukcesów PRL, które miały świadczyć o wyższości ustroju komunistycznego.

W Grenoble w lipcu 1974 r. Chruszczewski, Kuczka i Ion Hobana (Rumunia) poprowadzili wspólnie panel poświęcony fantastyce w krajach bloku wschodniego. Ostatniego dnia Euroconu głosowano nad kandydatura Poznania jako gospodarza kolejnej edycji - została przyjęta niemal jednogłośnie. Andre de Rycke, fan z Belgii, pisał: „Możemy się spodziewać, że będzie to konwent prawdziwie europejski, z uniwersyteckim tłumaczeniem symultanicznym, z tanim zakwaterowaniem i wyżywieniem oraz małymi wycieczkami (i Stanisławem Lemem)" ${ }^{20}$. To właśnie osoba najwybitniejszego polskiego pisarza SF mogła być główna przyczyna, dla której propozycja zorganizowania Euroconu w Polsce spotkała się z przychylnym przyjęciem. Na początku lat siedemdziesiątych twórczość Lema była już dobrze znana na rynku niemieckojęzycznym, w dużej mierze za sprawa jego promotora Franza Rottensteinera. Pojawiły się też pierwsze tłumaczenia na angielski, zarówno przekłady bezpośrednio z oryginałów (m.in. Cyberiada, tłum. Michael Kandel), jak i na podstawie innych wydań (Niezwyciężony, tłum. z niemieckiego Wendayne Ackerman), powstawały pierwsze prace krytycznoliterackie poświęcone twórczości Lema ${ }^{21}$. On sam miał zaś prowadzić serię wydawniczą prezentującą w Polsce najwybitniejsze - zdaniem Lema - dzieła światowej fantastyki ${ }^{22}$.

${ }_{18}$ M. Majowski, Polska Ludowa zaprasza. Polityka turystyczna w czasach Edwarda Gierka, Warszawa 2008, s. 45.

${ }^{19}$ Indywidualna turystyka zagraniczna była jednym z głównych źródeł pozyskiwania dewiz. Więcej na ten temat zob. P. Sowiński, Turystyka zagraniczna $w$ Polsce $w$ latach 1956-1980, „Dzieje Najnowsze” 2002, nr 1, s. 135-144.

20 A. De Rycke, Eurocon 2, „SF-Magazine”, IX 1974, nr 39, s. 53.

${ }^{21}$ Należy przy tym podkreślić, że Lem nie odniósł sukcesu komercyjnego na rynku anglojęzycznym, choć krytycy wysoko oceniali jego twórczość. Poszczególne tytuły sprzedawały się w kilku tysiącach egzemplarzy. Lem - istota nieznana, wywiad z Franzem Rottensteinerem, w: M. Oramus, Bogowie Lema, Przeźmierowo 2006, s. 125-134.

22 Seria „Stanisław Lem poleca” skończyła się na czterech tomach - z przyczyn politycznych. Kłopoty z wydaniem kolejnych książek, przede wszystkim Czarnoksiężnika 
Kongres nie mógł jednak odbyć się w Poznaniu bez zgody władz - zarówno lokalnych, jak i krajowych. Można przypuszczać, że jeszcze przed Euroconem w Grenoble Chruszczewski sondował taką możliwość, a formalności dopełniono w marcu 1975 r., gdy do Poznania przyjechali Péter Kuczka i Jean-Paul Cronimus, sekretarze generalni Europejskiego Komitetu Science Fiction. Delegaci ESFC spotkali się z wiceprezydentem Poznania Andrzejem Wituskim, który oficjalnie potwierdził wolę goszczenia Euroconu; w rozmowach uczestniczyli też przedstawiciele KC i KW PZPR oraz Związku Literatów Polskich $^{23}$. Utworzono komitet organizacyjny, w którym znaleźli się reprezentanci władz miejskich i wojewódzkich, KW PZPR, ZLP oraz lokalnych organizacji artystycznych; Chruszczewski objął funkcję sekretarza, a stanowisko przewodniczacego powierzono Wituskiemu.

Pierwszą notatkę dotycząca Euroconu opublikowano w brytyjskim fanzinie „Checkpoint” już w październiku 1974 r. Konwent zapowiadano na maj lub czerwiec 1976 r. (taki termin podano w Grenoble), spodziewano się tė̇, że Lem będzie przewodniczyć obradom. Wszelkie sugestie i pomysły dotyczące konwentu przyjmowali przedstawiciele ESFS: Pierre Versins (przewodniczący), Jean-Paul Cronimus (działacz francuskiego fandomu, współorganizator Euroconu w Grenoble, sekretarz ESFS ds. krajów Europy Zachodniej) oraz Kuczka (sekretarz ds. krajów Europy Wschodniej). Twórcy i fani fantastyki pragnacy wziąć udział w konwencie mieli się zgłaszać do lokalnych pośredników - w przypadku Wielkiej Brytanii był to Vernon Brown, działacz fandomu z Birmingham ${ }^{24}$. Pół roku później podano kolejne, bardziej szczegółowe informacje: termin Euroconu został ostatecznie wyznaczony na 19-22 sierpnia, a koszt udziału dla uczestników z zagranicy wynosił 10 dolarów. Dla fanów z Zachodu nie była to suma zawrotna, ale zauważalna - większość zapowiadanych wówczas konwentów kosztowała ok. 5-8 dolarów. Rejestracja zgłoszeń miała trwać do końca grudnia 1975 r., jednak - jak wynika z publikowanych później zapowiedzi w amerykańskich fanzinach - ostatecznie została przedłużona do końca marca 1976 r. ${ }^{25}$

Obowiąek wcześniejszej rejestracji i opłacenia uczestnictwa istniał także na wielu konwentach zachodnich - chodziło głównie o zarezerwowanie odpowiedniej liczby miejsc hotelowych dla osób bioracych udział w danej imprezie. W przypadku poznańskiego Euroconu uczestnikom również zapewniano zakwaterowanie (za dodatkową opłata, szacowaną na ok. 30 dolarów), ale

z Archipelagu Ursuli K. Le Guin (ze względu na osobę tłumacza - Stanisława Barańczaka), sprawiły, że w 1978 r. Lem zrezygnował z serii i ogłosił zerwanie współpracy z Wydawnictwem Literackim.

${ }^{23}$ Archiwum Akt Nowych (dalej: AAN), LVI-1835, Informacja z przebiegu prac przygotowawczych, 20 I 1976, s. 7.

${ }^{24}$ Eurocon III, „Checkpoint”, 10 X 1974, nr 54, s. 2.

25 „Luna Monthly” 1976, nr 62, s. 10; „SF\&F Newsletter”, 17 VII 1976, s. 6. 
wcześniejsze zgłoszenia były potrzebne z jeszcze jednego powodu. „Ze względu na charakter omawianej imprezy, jej wymowę propagandowa i przyjazd znacznej grupy przedstawicieli kultury burżuazyjnej z krajów kapitalistycznych zachodzi konieczność podjęcia stosownych działań mających na celu operacyjno-polityczne zabezpieczenie III Kongresu Science Fiction"26 - pisał w połowie maja 1976 r. ppłk Krzysztof Majchrowski z Departamentu III MSW, zajmujący się rozpracowywaniem środowiska literackiego. Wszyscy goście z krajów kapitalistycznych mieli być sprawdzeni w kartotece ogólnoinformacyjnej i operacyjnej Departamentu I MSW, zwłaszcza pod kątem ich ewentualnych kontaktów z opozycją demokratyczną w PRL.

Eurocon został objęty sprawą obiektową o kryptonimie „Nemo”. W planie działań przewidywano m.in. wykorzystanie tajnych współpracowników ze środowiska literackiego do informowania o działaniach uczestników kongresu i kontaktach między gośćmi z zagranicy a obywatelami PRL oraz kontrolę zachowania wytypowanych uczestników kongresu przy wykorzystaniu możliwości technicznych wydziałów „T” i „B” (włącznie z prowadzeniem tajnych przeszukań). Szczególna „opieka” operacyjną mieli być otoczeni twórcy związani z opozycją: Stanisław Barańczak, Ryszard Krynicki (sygnatariusze Listu 59) i Egon Naganowski oraz Przemysław Bystrzycki, cichociemny, wiceprezes poznańskiego oddziału ZLP. Chodziło o zdobycie informacji dotyczących „prób dotarcia do uczestników obrad, bądź [...] charakteru powiązań z uczestnikami kongresu, szczególnie z kk"27. Spodziewano się, że wykorzystają przyjazd gości zagranicznych do przekazania na Zachód informacji o sytuacji politycznej w Polsce - a plan pracy operacyjnej układano przecież jeszcze przed czerwcowymi protestami robotników w Radomiu, Ursusie i Płocku. Niepokój bezpieki wzbudził też konsul USA w Poznaniu, który zamierzał zaprosić na spotkanie gości anglosaskich oraz wybranych twórców polskich. Organizatorom konwentu polecono stanowczo odmówić zgody na takie „imprezy towarzyszące”. Ostatecznie na Eurocon nie przyjechał żaden gość z USA.

Pod lupą bezpieki znalazł się także Lem, jak donosił tajny współpracownik „Wł. Kowalski”, jedno opowiadanie z dopiero co wydanego tomu Maska „to zdecydowana aluzja o tendencyjnym charakterze, ironizująca i krytykująca nasze stosunki ustrojowe" ${ }^{28}$. Prawdopodobnie chodziło o tekst Edukacja Cyfrania (wątek orkiestry, stopniowo pożeranej przez czyhające w kącie Gorylium, o którym wszyscy wiedza, ale boją się to głośno powiedzieć), który w środowisku literackim był szeroko komentowany, jakkolwiek krytyki „stosunków

${ }^{26}$ Archiwum Instytutu Pamięci Narodowej, Oddział w Poznaniu (dalej: AIPN Po), 003/585, Pismo K. Majchrowskiego do Naczelnika Wydziału III KW MO w Poznaniu, k. 23.

${ }^{27}$ Ibidem, Plan działań operacyjnych zmierzający do operacyjno-politycznego zabezpieczenia III Europejskiego Kongresu Science Fiction, k. 15.

${ }^{28}$ Ibidem, Wyciag z informacji uzyskanej od t.w. ps. „Wł. Kowalski” podczas spotkania w dniu 15.06.1976 r., k. 299. 
ustrojowych" można się dopatrzeć jeszcze w co najmniej dwóch opowiadaniach z tego zbioru. Zdaniem grupy poznańskich dziennikarzy, do których zaliczał się i sam TW, miało to dowodzić, „że również i Lem musi należeć do opozycji w kraju" 29 . W rzeczywistości autor Solaris, chociaż sympatyzował z opozycja, daleki był od zaangażowania takiego jak Jan Józef Szczepański czy Stanisław Barańczak. TW zamierzał przeprowadzić wywiad z Lemem tuż przed kongresem, ale nie doszedł on do skutku, ponieważ pisarz, ku rozczarowaniu fanów, ostatecznie nie wzią udziału w Euroconie.

Dwa miesiące wcześniej Lem przeszedł operację usunięcia prostaty. Choć zabieg wydawał się nieskomplikowany, doszło do groźnych powikłańn ${ }^{30}$, które omal nie skończyły się dla pisarza tragicznie. Konieczny był dodatkowy pobyt w szpitalu, a później rekonwalescencja. Choć uczestnictwo w Euroconie raczej nie zaszkodziłoby jego zdrowiu, przebyta operacja stanowiła dobre usprawiedliwienie nieobecności, bo autor Solaris bynajmniej nie palił się do udziału w kongresie. Przez całe życie dystansował się od ruchu miłośników fantastyki, uważał się raczej za filozofa i futurystę niż pisarza science fiction, dlatego można z dużym prawdopodobieństwem przypuszczać, że i tak nie pojawiłby się na kongresie.

Gdyby przyjechał do Poznania, zostałby zakwaterowany „na zabezpieczonym obiekcie”, podobnie jak kilku gości z zagranicy, wytypowanych przez SB spośród kilkudziesięciu zgłoszonych przyjezdnych. Byli to: Jean Dubois (Belgia), André Bonnefry (Francja), Hans H. Frank (RFN) oraz dr Franz Rottensteiner (Austria). Dlaczego bezpieka zwróciła na nich uwagę? Według danych z kartoteki Ministerstwa Spraw Wewnętrznych (MSW) artysta Dubois (Jan Dubiski-Dubois) był Polakiem, żołnierzem AK i więźniem sowieckich łagrów, który po II wojnie światowej wyjechał na Zachód. Bonnefry na początku lat sześćdziesiątych pełnił funkcję attaché kulturalnego ambasady francuskiej; w tym czasie poddawano go inwigilacji, ale nie stwierdzono działań wykraczających poza obowiązki służbowe. Frank był członkiem rady naczelnej instytutu, z którego analiz korzystać miał niemiecki wywiad, ale MSW nie znalazło żadnych dowodów na jego bezpośrednie powiązania ze służbami. Dla polskiego czytelnika najbardziej interesująca postać w tym gronie to Rottensteiner, krytyk, tłumacz i wydawca, od kilku lat korespondujący z Lemem, później jego agent literacki na rynkach zagranicznych. Według charakterystyki sporządzonej przez MSW „posiada jakiś uraz do ustroju socjalistycznego, jednocześnie jest pełen sympatii do Polaków [...] nie jest on ani naszym wrogiem, ani przyjacielem" ${ }^{31}$.

\footnotetext{
${ }^{29}$ Ibidem.

30 Jan Józef Szczepański pisał: „Operacja przeprowadzona została najnowocześniejszą technika, ale w szpitalu nie działają łazienki i nikt nie sprząta ubikacji”. Po powrocie do domu Lem dostał krwotoku i zakażenia. Życie uratowali mu znajomi, wioząc go do szpitala w Katowicach. Cyt. za: W. Orliński, Lem. Życie nie z tej ziemi, Warszawa 2019, s. 318-319.

${ }^{31}$ AIPN Po, 003/585, Notatka informacyjna, 24.06.1976 r., k. 303.
} 


\section{Ludzie i gwiazdy}

Z doniesień tajnych współpracowników, „Rysia” i „Piotra”, wynikało, że $\mathrm{w}$ kolejnych miesiącach prace zwiąane z kongresem były głównym tematem spotkań poznańskiego zarządu ZLP. Nie budziło to entuzjazmu środowiska, w którym brakowało pisarzy i miłośników science fiction, oczywiście poza samym Chruszczewskim. Niektórzy poznańscy literaci uważali, że prezes oddziału podjął się organizacji Euroconu wyłącznie dla autopromocji - aby zyskać rozpoznawalność w innych środowiskach. „Miały miejsce wypowiedzi, iż Chruszczewski robi to głównie z myślą o sobie” 32 - informował „Ryś”. Atmosferę oczekiwania na wyjatkowe wydarzenie podgrzewała prasa. „Już dziś wiadomo, że przyjedzie ponad 250 pisarzy, plastyków, filmowców, ludzi radia i TV ze wszystkich krajów naszej części świata, a także obserwatorzy ze Stanów Zjednoczonych, Kanady i Australii” ${ }^{33}$ - donosiła „Gazeta Zachodnia”, a Bronisław Kledzik z Wydawnictwa Poznańskiego przekonywał: „Fakt ten określa wymownie rangę, jaką w życiu kulturalnym naszego kraju zajmuje ośrodek poznański” ${ }^{34}$.

Miejscowe władze zdawały sobie sprawę z potencjału Euroconu („ma to dla nas duże znaczenie propagandowe" ${ }^{35}$ ) i zadbały o odpowiednia oprawę. Początkowo planowano zakwaterowanie uczestników w Domu Studenckim „Jowita” położonym blisko hotelu „Merkury”, gdzie miał się odbyć kongres, ostatecznie jednak zdecydowano się przenieść obrady do gmachu Urzędu Wojewódzkiego, a noclegi - do otwartego w 1974 r. „Poloneza”. Był to najnowocześniejszy hotel w Poznaniu, cieszący się popularnością wśród gości z zagranicy oraz rodzimych dygnitarzy, gwiazd estrady i piłkarzy „Lecha”. Zakwaterowanie uczestników Euroconu $\mathrm{w}$ tym obiekcie podnosiło prestiż imprezy, ale z punktu widzenia SB miało także niezwykle praktyczny wymiar: ułatwiało pracę operacyjna dzięki aparaturze podsłuchowej zainstalowanej w hotelu (prawdopodobnie już w trakcie budowy). Półtora roku wcześniej w „Polonezie” odbył się kongres ZLP, którego uczestnicy „musieli mieć świadomość, że ściany mogą mieć uszy, a dokładnie - czułe mikrofony" ${ }^{36}$.

32 Ibidem, Wyciag z informacji uzyskanej od t.w. ps. „Ryśs” podczas spotkania w dniu 26.06.1976 r., k. 301.

${ }^{33}$ Ibidem, „Gazeta Zachodnia”, 12 VII 1976, wycinek dołączony do akt sprawy obiektowej „Nemo”, k. 315.

${ }^{34}$ U źródeł humanistycznej fantazji, „Głos Wielkopolski”, 14-15 VIII 1976, s. 3. Kledzik znany jest dziś jako właściciel wydawnictwa Media Rodzina, która wydała w Polsce cykl o Harrym Potterze. Jej współzałożycielem był Robert „Bob” Gamble (1937-2020), Amerykanin, który pod koniec lat pięćdziesiątych zaprzyjaźnił się z Lechem Jęczmykiem, zaprenumerował mu pismo „Fantasy and Science Fiction” i przesyłał nowości wydawnicze, dzięki czemu Jęczmyk - tłumacz, krytyk i redaktor - doskonale orientował się w zachodniej fantastyce.

${ }^{35}$ AIPN Po, 003/585, Pismo K. Majchrowskiego do Naczelnika Wydziału III KW MO w Poznaniu, k. 23.

${ }^{36}$ A. Franaszek, Herbert. Biografia, t. II: Pan Cogito, Kraków 2018, s. 448. 
Dobrego wrażenia miała dopełniać restauracja „W-Z”, zaliczana do najlepszych lokali w Poznaniu, w której zarezerwowano obiady i kolacje dla uczestników Euroconu. Na zakończenie planowano piknik w zabytkowym parku w Rogalinie. Obradom i dyskusjom, tłumaczonym symultanicznie na kilka języków (angielski, francuski, niemiecki, rosyjski i polski), towarzyszyć miały: przegląd filmów fantastycznonaukowych i wystawy, kolejno: książek i magazynów science fiction, plastyki i grafiki polskiej, międzynarodowej sztuki science fiction oraz sowieckiego malarstwa o tematyce fantastycznej. Nakładem Wydawnictwa Poznańskiego miała się ukazać antologia opowiadań pisarzy z krajów socjalistycznych Ludzie i gwiazdy.

Ze strony polskiej wśród zapowiedzianych gości znaleźli się artyści (Gustaw Zemła, Andrzej Strumiłło), filmowcy (Bohdan Poręba, Czesław Petelski), popularyzatorzy nauki (Zbigniew Przyrowski, Maciej Iłowiecki), krytycy (Wojciech Natanson, Ryszard Handke), wreszcie literaci - zarówno twórcy science fiction (Zajdel, Boruń, Fiałkowski), jak i inni (Edward Stachura, Aleksander Minkowski). Młode pokolenie autorów reprezentować mieli laureaci konkursu na opowiadanie fantastyczne ogłoszonego rok wcześniej przez wielkopolski miesięcznik społeczno-kulturalny „Nurt”, przy udziale m.in. Wydawnictwa Poznańskiego oraz poznańskiego oddziału ZLP. Na swoich łamach konkurs ten reklamowało też pismo „Problemy”, a przewodniczącym jury był sam Chruszczewski. Nic dziwnego, że jedną z nagród, oprócz pieniędzy i druku wyróżnionych utworów, stanowił udział w obradach Euroconu. Dwaj spośród laureatów, Jacek Sawaszkiewicz i Wiktor Żwikiewicz, zyskali spora popularność w kolejnej dekadzie.

Kilkunastoosobowa reprezentację ${ }^{37}$ zgłosił Ogólnopolski Klub Miłośników Fantastyki i Science Fiction (OKMFiSF), pierwsza organizacja fandomowa obejmująca, przynajmniej w teorii, całą Polskę. OKMFiSF powstał pół roku wcześniej na bazie dwóch warszawskich środowisk, ale nie był samodzielnym stowarzyszeniem - działał w strukturach Socjalistycznego Związku Studentów Polskich Uniwersytetu Warszawskiego. W sierpniu 1976 r. miał zrzeszać już kilkuset miłośników fantastyki, m.in. z Warszawy, Szczecina, Poznania, Białegostoku, Katowic i innych ośrodków; poznański działacz Mieczysław Kurpisz współpracował przy organizacji Euroconu. Wspomnienia osób zaangażowanych wówczas w ruch fanowski każą podchodzić z dystansem do liczb podawanych w oficjalnych sprawozdaniach, ale niewattpliwie już przed Euroconem klub organizował spotkania z pisarzami, redaktorami i tłumaczami, dyskusje i pokazy filmów, współpracował z Krajową Agencją Wydawniczą ${ }^{38}$.

${ }^{37}$ A. Wójcik, Rozwój i działalność OKMFiSF w latach 1976-1980, „Fandomas” 1986, nr 3, s. 8.

${ }^{38}$ W ramach tej współpracy OKMFiSF redagował serię wydawniczą science fiction „Fantazja Przygoda - Rozrywka”. OKMFiSF zakończył działalność na początku lat osiemdziesiątych, w 1981 r. część byłych działaczy założyła Polskie Stowarzyszenie Miłośników Fantastyki, które przetrwało do końca PRL. Więcej na ten temat zob. A. Wierzchowska, Wyobraźnia koncesjonowana. Polskie Stowarzyszenie Miłośników Fantastyki 1981-1989, w: Nie (tylko) 
Jego reprezentanci uczestniczyli też w kolejnych międzynarodowych konwentach, m.in. Worldconie w Brighton w 1979 r. ${ }^{39}$ oraz Euroconie ' $80 \mathrm{w}$ Stresie (Włochy). Poznański kongres był dla studenckich działaczy pierwsza „,szkoła konwentowania", która już wkrótce przydała się przy własnych inicjatywach OKMFiSF: międzynarodowych seminariach „Orbity przyjaźni” czy konwentach miłośników fantastyki. Nawiązane wówczas relacje z pisarzami zaowocowały też kilkoma zgodami na druk zagranicznych tekstów za złotówki (o uwarunkowaniach wydawniczych PRL poniżej) i późniejszymi publikacjami opowiadań w „Fantastyce” ${ }^{40}$, której współzałożycielami i redaktorami byli m.in. obecni na Euroconie działacze OKMFiSF.

\section{Poniedziałek zaczyna się w sobotę}

Zbliżający się Eurocon budził zainteresowanie jako pierwszy konwent w kraju komunistycznym, w którym mogło uczestniczyć tak wielu przedstawicieli Zachodu. Część z nich skorzystała z okazji do zwiedzania, tak jak grupa belgijskich fanów czy brytyjski pisarz Aldiss, który „przyjechał do Poznania z fasonem: wynajał samochód kempingowy, którym zabrał żonę Margaret i trójkę wówczas jeszcze nieletnich dzieci" ${ }^{41}$. Miał on jeszcze jeden powód do odwiedzin - honorarium za wydane w Polsce książki. Zgodnie z obowiązujacymi regulacjami, których ofiarą stał się wcześniej Philip K. Dick ${ }^{42}$, zagraniczni pisarze otrzymywali czasem wynagrodzenie (częściowo lub wyłącznie) w złotówkach, których nie dało się wymienić i wywieźć za granicę. Mogli je oczywiście wydać na miejscu, ale należało się wybrać do Polski - a konwent fantastyki stanowił ku temu doskonała okazję, z której w kolejnej dekadzie korzystali autorzy science fiction, m.in. Poul Anderson, James White czy Frederik Pohl ${ }^{43}$.

Partia? Organizacje społeczne w Polsce Ludowej 1944-1989 - geneza, funkcjonowanie, znaczenie, red. T. Ruzikowski, Warszawa 2018, s. 351-379.

39 „Informator Miłośnika Fantastyki” 1979, nr 9-10, s. 1-4.

${ }^{40}$ Jestem $w$ fandomie od 1976 r. Wywiad z Jackiem Rodkiem, w: W. Sedeńko, op. cit., s. 313.

${ }^{41}$ W. Bukato, op. cit., s. 31.

${ }^{42}$ W. Orliński, op. cit., s. 341-345.

${ }^{43}$ Szerzej proces ten opisuje w wywiadzie Wiktor Bukato (W. Sedeńko, op. cit., s. 260-263). Wydawnictwa drukujące fantastykę, m.in. Krajowa Agencja Wydawnicza czy Alfa, zwykle nie mogły liczyć na stosowny przydział dewiz, by zapłacić pisarzom w innej walucie, stąd konieczność uzyskania zgody na honorarium w złotówkach. Z podobnym problemem borykały się też wydawnictwa o innym profilu, np. architektonicznym. Zob. wywiad z Barbara Gadomska i Andrzejem Karpowiczem, https://autoportret.pl/artykuly/wielki-swiat-zajmowal-sie-nadbudowa-a-my-wciaz-nie-moglismy-sie-uporac-z-baza-i/2/ (dostęp: 12 X 2020). Według Jęczmyka przy okazji wizyty w Polsce Aldiss chciał za swoje honorarium kupić „nieduży, gustowny jacht”, ale okazało się to niemożliwe. Rakietowe szlaki, red. L. Jęczmyk, t. II, Stawiguda 2011, s. 5. 
Większość gości była obecna w Poznaniu już 18 sierpnia, kiedy w „Polonezie” odbyło się pierwsze spotkanie informacyjne. Po konferencji ESFC i zwiedzaniu miasta część fanów zgromadziła się wieczorem w hotelowym barze „na drinka lub drinków kilka” ${ }^{4}$. Oficjalne rozpoczęcie Euroconu miało miejsce następnego dnia w sali Urzędu Wojewódzkiego. Kongres otworzył Władysław Śleboda, prezydent Poznania. Inauguracyjny referat „Dlaczego kongres science fiction?” wygłosił Chruszczewski, a ze względu na nieobecność Lema przewodnictwo nad obradami obją pisarz i tłumacz Jan Koprowski, sekretarz Zarządu Głównego ZLP. Po południu w poznańskim Pałacu Kultury odbyło się przyjęcie dla uczestników Euroconu, wydane przez prezydenta miasta. Tego dnia w Biurze Wystaw Artystycznych otwarto też dwie ekspozycje towarzyszące kongresowi: obrazów Jerzego Nowosielskiego oraz obrazów i grafik młodych artystów, pt. „Fantastyka i metafora”. W gmachu Urzędu Wojewódzkiego prezentowano książki i czasopisma fantastycznonaukowe nadesłane $\mathrm{z}$ różnych krajów europejskich, w tym fundamentalne dzieła francuskiej SF (włącznie z pierwszymi wydaniami wielu tytułów) ze zbiorów Pierre'a Versinsa, przewodniczącego ESFS, a także zagraniczne edycje powieści Lema. Według przedstawiciela Jugosławii właśnie ta wystawa, gromadzacca publikacje z całego kontynentu, była „najfantastyczniejsza" ${ }^{45}$. Skromnie wypadła natomiast wystawa malarstwa, grafiki i medali science fiction z różnych krajów, na której brakowało prac najbardziej cenionych artystów ${ }^{46}$.

Obradom towarzyszyły pokazy filmów fantastycznonaukowych w kinie „Apollo” - każdego wieczoru wyświetlano dwa tytuły. Przegląd rozpoczął się pokazem jednego z najsłynniejszych dzieł kinematografii science fiction, czyli 2001: Odyseja kosmiczna Stanleya Kubricka, następnie wyświetlono polski Lokis. Rękopis profesora Wittembacha (reż. Janusz Majewski). Nie był to, wbrew nazwie imprezy, film science fiction, lecz kostiumowy horror, którego akcja toczy się w XIX w. W kolejnych dniach zaprezentowano: Akcję Bororo (Czechosłowacja, reż. Otakar Fuka) i W gwiezdnym pyle (NRD, reż. Gottfried Kolditz; w filmie tym wystapił Leon Niemczyk), Wspomnienia z przyszłości (RFN, reż. Harald Reinl), głośną ekranizację Solaris Lema ${ }^{47}$ (ZSRS, reż. Andriej Tarkowski), Spotkanie na Kasjopei (ZSRS, reż. Riczard Wiktorow), Świat Dzikiego Zachodu (USA, reż. Michael Crichton), Podwodna Odyseje (Kanada, reż. Daniel Petrie) oraz Zagtadę Japonii (Japonia, reż. Andrew Meyer, Shirô Moritani). Przegląd uzupełniała umieszczona w hallu wystawa plakatu filmowego science fiction.

${ }^{44}$ V. Brown, The Polish Eurocon, „Checkpoint”, XI 1976, nr 76, s. 3.

${ }^{45}$ Z. Živković, Eurokon 76, „Galaksija” 1976, nr 10, s. 30.

${ }^{46}$ G.F. Pizzo, Il $3^{\circ}$ Congresso Europeo di Fantascienza, „Robot. Rivista di fantascienza” 1976, nr 8, s. 110.

${ }^{47}$ Warto pamiętać, że samemu pisarzowi film się nie podobał, a z reżyserem pokłócił się już na etapie omawiania zarysu scenariusza. W. Orliński, op. cit., s. 304-306. 
19 sierpnia przed godz. 15.00 w Poznaniu obecnych było 174 uczestników kongresu, w tym 157 cudzoziemców (większość oczywiście z krajów socjalistycznych; najliczniejsze delegacje przysłały: ZSRS, Węgry oraz NRD) ${ }^{48}$. Zapewne jeszcze kilka lub kilkanaście osób przyjechało wieczorem lub kolejnego dnia. Ostatecznie - jak wynika z danych uzyskanych przez SB - w Euroconie udział wzięło ok. 200 twórców i fanów z 20 krajów, w tym ok. 90 osób z krajów kapitalistycznych (najwięcej z Francji i Belgii) ${ }^{49}$. Vernon Brown, jeden z dwóch fanów z Wielkiej Brytanii, został usadzony za stołem prezydialnym wraz z delegacjami państwowymi. Wypytujący go dziennikarze nie mogli uwierzyć, że jest po prostu miłośnikiem science fiction i nie zajmuje się zawodowo pisarstwem lub krytyka - większość uczestników Euroconu, także z krajów zachodnich, reprezentowała redakcje pism lub oficjalne stowarzyszenia pisarzy ${ }^{50}$.

Na program kongresu składały się prelekcje, m.in. Czesława Chruszczewskiego, Voicu Bugariu (Estetyka w twórczości science fiction), Jewgienija Brandisa (Fantastyka naukowa i człowiek we współczesnym świecie), Konrada Fiałkowskiego (Model rzeczywistości pomyślanej), Manuela van Loggema (Science fiction i literatura) i Briana Aldissa (Science Fiction $w$ Wielkiej Brytanii), a także table ronde - dyskusje pisarzy, redaktorów i krytyków, z udziałem publiczności. Zabrakło natomiast wystapienia Versinsa o fantastyce francuskojęzycznej, ponieważ przewodniczący ESFC nie zdążył go przygotować. Aldiss pisał później, że referaty, poza jednym zachodnim wyjątkiem (chodzi zapewne o van Loggema), były „niewyobrażalnie głupie [...]. Jeden za drugim delegaci z Europy Wschodniej deklarowali niewzruszony optymizm względem przyszłości, przewidując doskonałość nauki oraz marksistowski światopogląd ludzkości" ${ }^{51}$. Mniej krytyczny okazał się Jozef Van den Borre z Belgii, który zanotował tylko, że wystapienia nie były porywające i sprowadzały się raczej do odczytywania przygotowanego tekstu z kartki ${ }^{52}$. Pochwalił za to referat samego Aldissa, który miał zgoła inny charakter - według Browna podczas tego jedynego publiczność chichotała ${ }^{53}$. Brytyjski pisarz tłumaczył później w wywiadzie: „tego typu spotkania pełne są oficjalnych mów [...]. By rozładować więc atmosferę mówiłem nie tylko o rzeczach wielkich, ale i o śmierdzacych ubikacjach. To sprowadza temat na ziemię i rozluźnia słuchaczy" 54 . Mniej „ugłaskane” było sobotnie table ronde z udziałem kilkunastu pisarzy i krytyków, głównie z Francji i Hiszpanii,

\footnotetext{
${ }_{48}$ AIPN Po, 003/585, Notatka służbowa dot. III Kongresu SF, 21.08.1976 r., k. 364.

${ }^{49}$ Ibidem, Informacja dot. III Kongresu SF, 30.08.1976 r., k. 371.

${ }^{50}$ V. Brown, op. cit., s. 3.

51 B. Aldiss, The SF Conferences in Poznan and Dublin, https://www.depauw.edu/sfs/notes/ notes12/notes.html (dostęp: 14 XI 2020).

52 J. Van den Borre, Eurocon 3, „Rigel” 1977, nr 57, s. 21-22.

${ }^{53}$ V. Brown, op. cit.

54 Jestem humanista... Rozmowa z Brianem Aldissem, „Nurt” 1976, nr 12, s. 20-21.
} 
broniących twórczej roli pesymizmu w literaturze, a także zorganizowane ad hoc niedzielne wystapienie Bernarda Goordena ${ }^{55}$.

Po obradach zaczynało się prawdziwe życie konwentowe. Włoski dziennikarz wspominał Versinsa improwizujacego „walkę małp” z fanem, Cronimusa, który wyłaniał się jak spod ziemi, by zrobić kolejne zdjęcie, perfekcyjny włoski Hobany, wywiady i ożywione rozmowy toczone jednocześnie w kilku językach ${ }^{56}$. Oficjalny protokół ustępował miejsca luźnej atmosferze, a wódka przełamywała bariery językowe. „Polacy okazali się nadzwyczaj miłymi gospodarzami. Ich życzliwość, serdeczność względem cudzoziemców [...] była krzepiąca" ${ }^{57}$ - chwalił Aldiss, który wysoko ocenił także kwestie organizacyjne: jakość tłumaczenia, warunki zakwaterowania, wreszcie zaangażowanie lokalnych władz w przygotowanie Euroconu. Podobne odczucia miał Brown: obiady w „W-Z” były niedrogie, obfite i smaczne, a przyjęcie powitalne i piknik - wręcz wystawne ${ }^{58}$. Nieprzejednany pozostał natomiast TW „Ryśs” działający w środowisku poznańskich literatów. Jego zdaniem „organizacja [...] imprezy pochłania znaczne sumy pieniędzy, co na pewno nie jest proporcjonalne do efektów propagandowych i wydźwięku w skali europejskiej”. Za najjaśniejszy punkt Euroconu uznał „przybycie i wystapienie członka delegacji radzieckiej - kosmonauty Leonowa" ${ }^{59}$.

\section{Gwiazdy moim przeznaczeniem}

Leonow „potrafił oczarować słuchaczy”60 - przyznał Van den Borre. Kosmonauta malowniczo opowiadał uczestnikom Euroconu o swoich przeżyciach w przestrzeni pozaziemskiej, nawiązując do przewidywań Konstantego Ciołkowskiego i klasyków science fiction, ale nie uczestniczył w całym kongresie. Spotkał się z przedstawicielami KW PZPR, gdzie wręczono mu odznakę upamiętniająca zdobycie Poznania przez Armię Czerwoną w lutym 1945 r., a później razem z pozostałymi delegatami ZSRS zwiedził muzeum na Cytadeli i złożył kwiaty pod pomnikiem poległych żołnierzy sowieckich. „Chodząc po Cytadeli pojąłem, że w duszach mieszkańców tego miasta trwa wdzięczność i pamięć o ofiarach poniesionych przy wyzwalaniu Poznania"61 - opowiadał. Program wizyty Leonowa wpisywał się w politykę „umacniania przyjaźni” ze

\footnotetext{
55 J. Le Clerc de La Herverie, Eurocon 3: Impressions fugitives d'un dévoureur de fusées, „Fiction” 1976, nr 11 (274), s. 169.

${ }^{56}$ G.F. Pizzo, op. cit., s. 113.

57 B. Aldiss, op. cit.

${ }^{58}$ V. Brown, op. cit., s. 3.

${ }^{59}$ AIPN Po, 003/585, Wyciąg z informacji uzyskanej od t.w. ps. „Ryś” podczas spotkania w dniu 16.09.1976 r., k. 373.

${ }^{60}$ J. Van den Borre, op. cit., s. 21-22.

${ }^{61}$ Ziemia to wspólny dom wszystkich ludzi, „Głos Wielkopolski”, 21-22 VIII 1976, s. 2.
} 
Związkiem Sowieckim - wszak ledwie pół roku wcześniej Sejm PRL przegłosował zmianę konstytucji, wpisujac do niej ową przyjaźń. Kilka dni później, już w Warszawie, Leonow otrzymał honorową odznakę Towarzystwa Przyjaźni Polsko-Radzieckiej za „zasługi w umacnianiu więzi przyjaźni między narodami Polski i ZSRR”62.

„Człowiek Kosmosu tłumaczył cierpliwie, gładząc z widocznym wzruszeniem płowe główki [...] i tylko słychać było wspólny śmiech - dzieci i bohatera Kosmosu” ${ }^{63}$ - relacjonował z emfazą dziennikarz „Głosu Wielkopolskiego" udział Leonowa w pikniku kończącym Eurocon. Niezależnie od pompatycznie brzmiących artykułów w prasie można przyjąć za pewnik, że spotkanie $\mathrm{z}$ kosmonauta (i to $\mathrm{z}$ takim osiągnięciem) było atrakcją nie tylko dla uczestników kongresu. Jeszcze w lipcu gazety relacjonowały misję Sojuz 21, niemal codziennie donosząc o stanie zdrowia kosmonautów i prowadzonych badaniach, a także - choć z mniejszym zaangażowaniem - postępy amerykańskiego programu Viking. Wyobraźnię najbardziej pobudzał jednak inny „gwiezdny” temat: możliwość lotu w kosmos pierwszego Polaka. Kilka tygodni przed Euroconem w Moskwie podpisano porozumienie w sprawie udziału państw członkowskich programu Interkosmos w lotach załogowych organizowanych przez ZSRS. W jednym z wywiadów udzielonych w Poznaniu sam Leonow potwierdził, że niebawem przedstawiciele innych krajów zostana zaproszeni do uczestnictwa w misjach, a „Gazeta Zachodnia” zapewniała, że „Dorobek naukowy [...] daje naszemu krajowi dobra pozycję wyjściowa”" Rzeczywiście mjr Mirosław Hermaszewski poleciał jako drugi z grupy, ale o kolejności zadecydowały względy polityczne. Wobec pogłębiającego się kryzysu gospodarczego i ukształtowania się opozycji demokratycznej władze PRL potrzebowały sukcesu łatwego do wykorzystania w propagandzie, a lot Polaka w kosmos idealnie się do tego nadawał ${ }^{65}$. Wizyta Leonowa, choć nie była bezpośrednio związana z tym wydarzeniem, wpisywała się w propagandowy kontekst: budzenie zainteresowania eksploracją kosmosu i podkreślanie polsko-sowieckiej współpracy w nauce i technice.

Oficjalna część Euroconu zakończyła się w niedzielę przyznaniem nagród i wyróżnień oraz wyborem nowego Europejskiego Komitetu Science-Fiction - Chruszczewski otrzymał stanowisko wiceprzewodniczacego, został też uhonorowany nagroda specjalną za dorobek literacki i organizacyjny. Główne nagrody, czyli Złote Krople Fantazji - rzeźby autorstwa Józefa

${ }^{62}$ Złota odznaka TPPR dla A. Leonowa, „Gazeta Zachodnia”, 25 VIII 1976, s. 1.

${ }^{63}$ Wspaniaty człowiek XX wieku, „Głos Wielkopolski”, 24 VIII 1976, s. 2.

${ }^{64}$ Polski kosmonauta $w$ międzynarodowej załodze stacji orbitalnej „Salut”, „Gazeta Zachodnia", 14-15 VIII 1976, s. 1.

${ }^{65}$ Nota bene zmiennik Hermaszewskiego, Zenon Jankowski pochodził z Poznania. Więcej na temat udziału PRL w programie Interkosmos oraz propagandowego wykorzystania lotu Hermaszewskiego zob. P. Szulc, Mirosław Hermaszewski - kosmiczna ikona propagandy sukcesu, „Dzieje Najnowsze” 2012, nr 4, s. 45-62. 
Kopczyńskiego - dostali: nieobecny Lem za twórczość literacka, Leonow za malarstwo oraz francuskie wydawnictwo Presense de Futur za działalność popularyzatorska. Ponadto przyznano kilkanaście mniejszych wyróżnień w postaci złotych plakietek „Gwiazdolot”, również autorstwa Kopczyńskiego. Śmiało można powiedzieć, że żadna narodowa reprezentacja nie wyjechała z Polski bez nagrody. Wcześniej wybrano też gospodarza kolejnej edycji konwentu: o goszczenie Euroconu '78 ubiegały się NRD (Berlin) i Włochy (Ferrara). W wyrównanym głosowaniu (10 do 9 głosów) zwyciężyły Niemcy. Wkrótce po zakończeniu poznańskiego kongresu okazało się jednak, że NRD nie będzie w stanie wywiązać się z zobowiązania. Ostatecznie rolę gospodarza IV Euroconu przejęła Bruksela. Do krajów komunistycznych konwent wrócił w następnej dekadzie: w 1983 r. gościł w Lublanie, w 1986 r. w Zagrzebiu, w 1988 r. - w Budapeszcie.

Dopełnieniem kongresu był uroczysty piknik, wydany przez wojewodę wielkopolskiego, „z muzyka, ogniskiem, fajerwerkami i jeszcze większą ilościa wódki” 66 w Gułtowach, w parku otaczającym zabytkowy pałac - wówczas siedzibę PGR. Zdaniem reprezentanta Włoch piknik nie miał wiele wspólnego z fantastyką naukowa, ale działał na wyobraźnię: ,jedzenie na świeżym powietrzu, śpiewy i tańce w rytm ludowej muzyki, blask sztucznych ogni" ${ }^{67}$. Oprawę artystyczną zapewnił Zespół Pieśni i Tańca „Wielkopolska”; w pierwszej parze tańczył oczywiście „Kosmonauta z piękną Wielkopolanką"68.

\section{Najdalszy brzeg}

Podczas Euroconu „nie stwierdzono faktów wrogich czy szkodliwych wypowiedzi bądź działań" ${ }^{69}$ ani prób nawiązania nieoficjalnych kontaktów z polskimi twórcami. W relacjach opublikowanych w zachodnich pismach i fanzinach nie ma też śladu dyskusji czy refleksji politycznych, a jedynym odniesieniem do sytuacji gospodarczej jest wzmianka o racjonowaniu mięsa w $\mathrm{PRL}^{70}$. Zdaniem organizatorów kongres „umożliwił przekazanie treści ideologicznych (humanizm socjalistyczny, optymizm utworów SF)"71, choć goście z Zachodu - jak cytowany wcześniej Aldiss - powszechnie kpili z owych treści. Chwalili za to jakość organizacji: ,żaden kongres s-f nie był tak dobrze zorganizowany jak tegoroczny, poznański. [...] Nie dziwię się, że polska gościnność znana jest

66 B. Aldiss, op. cit.

${ }^{67}$ G.F. Pizzo, op. cit., s. 109.

${ }^{68}$ Wspaniaty czlowiek XX wieku..., s. 2.

${ }^{69}$ AIPN Po, 003/585, Informacja dot. III Kongresu SF, 30.08.1976 r., k. 371.

${ }^{70}$ V. Brown, op. cit., s. 3.

${ }^{71}$ AAN, LVI-1835, Ocena przebiegu III Kongresu Europejskiego Science Fiction (Poznań 19-22 VIII 1976), [s. 6]. 
na świecie"72 - przekonywał brytyjski pisarz. Warto jednak podkreślić, że na świecie konwenty organizowały zwykle lokalne kluby fantastyki, czasem przy wsparciu centrów kultury lub lokalnych władz, w Poznaniu zaś kongres od początku do końca koordynowany był przez władze miasta i województwa oraz oddział ZLP (przy dużej niechęci tych ostatnich), dlatego mimo ograniczeń politycznych możliwości finansowe i logistyczne okazały się większe niż w przypadku wielu zachodnich imprez. Rok 1976 mógł też być ostatnim momentem na organizację Euroconu w PRL - w późniejszych latach prawdopodobnie nie podjęto by ryzyka przyjazdu tak wielu gości z Zachodu, a na pewno nie przyjęto by ich tak wystawnie.

Było to ostatnie duże przedsięwzięcie Chruszczewskiego. Próbował jeszcze, wraz ze znajomymi literatami, stworzyć czasopismo poświęcone science fiction, ale tego zamiaru nie udało mu się zrealizować. Zmarł w lutym $1982 \mathrm{r}$. Pół roku później zaczęła się ukazywać „Fantastyka”, założona i redagowana już przez zupełnie inne środowisko. W pierwszym numerze poinformowano o pośmiertnym przyznaniu Chruszczewskiemu godności członka honorowego ESFS - w uznaniu zasług dla europejskiego ruchu SF.

Poznański kongres nie odegrał dużej roli w rozwoju polskiego fandomu. Środowisko fanowskie - tak jak wszędzie na świecie - organizowało się oddolnie, a tylko kilku spośród późniejszych działaczy klubowych wzięło udział w III Euroconie. Chociaż zwraca się uwagę, że to właśnie w Poznaniu „polscy fantaści się policzyli, zobaczyli swoją siłę i moc”73, w środowiskowym przekazie pamięć o Euroconie nie funkcjonuje w takim stopniu, jak powstanie „Fantastyki”, działalność Ślaskiego Klubu Fantastyki czy odbywające się od 1985 r. konwenty ogólnopolskie - Polcony.

Prawdziwe znaczenie III Euroconu leży w jego międzynarodowym charakterze. We wspomnieniach uczestników wielokrotnie pojawiają się wzmianki o nawiązanych wówczas kontaktach, które zaowocować miały tłumaczeniami, prezentacjami i antologiami, a także wzajemnymi wizytami na konwentach narodowych. Versins przypominał, że „W Poznaniu [...] spotkali się po raz pierwszy, w takim wymiarze, twórcy SF ze Wschodu i Zachodu"74. Wtórował mu Zoran Živković: „Jednym z głównych celów takich zjazdów jest spotkanie miłośników science fiction z najodleglejszych rejonów Europy. Nic nie zastapi osobistego poznania, żadna korespondencja nie może się równać z dyskusja na żywo" "75. Pod tym względem poznański Eurocon z całą pewnością sprostał oczekiwaniom.

\footnotetext{
${ }^{72}$ Podró ż petna nadziei, wywiad z Brianem Aldissem, „Polityka” 1976, nr 42.

${ }^{73}$ Wypowiedź Marka Oramusa. T. Pindel, Historie fandomowe, Wołowiec 2019, s. 10.

${ }^{74}$ S-F to bardziej stan duszy niż rodzaj literacki, „Nurt” 1976, nr 10, s. 24.

${ }^{75}$ Z. Živković, op. cit., s. 31.
} 


\section{Streszczenie}

Rosnąca popularność science fiction, rozwój środowisk fanowskich i odprężenie w stosunkach politycznych Wschód-Zachód sprzyjały organizacji międzynarodowych konwentów fantastyki. W sierpniu 1976 r. w Poznaniu odbyła się trzecia - po Trieście i Grenoble - edycja Europejskiego Kongresu Science Fiction (Euroconu), która zgromadziła blisko 200 twórców i miłośników fantastyki z 20 krajów. Dyskusjom o literaturze towarzyszyły liczne atrakcje, m.in. przegląd filmowy, wystawy oraz przyjęcia. Gwiazdą imprezy był sowiecki kosmonauta Aleksiej Leonow; ku rozczarowaniu wielu uczestników w Euroconie nie uczestniczył za to Stanisław Lem. Goście z Zachodu znaleźli się pod obserwacją Służby Bezpieczeństwa, ale w trakcie konwentu nie odnotowano żadnych działań o charakterze politycznym. Władze komunistyczne zaangażowały się w organizację imprezy, uznając ją za doskonałe narzędzie propagandowe, ale przekaz ideologiczny został przyćmiony przez typowe dla konwentów osobiste kontakty i nieformalną atmosferę.

\section{The Futurological Convention. Eurocon 1976 in Poznań}

The growing popularity of science fiction, the development of fan circles and the relaxation of East-West political relations favoured the organisation of international science fiction conventions. In August 1976, the third - after Triest and Grenoble - edition of the European Science Fiction Convention (Eurocon) took place in Poznan, which gathered almost two hundred authors and fantasy fans from twenty countries. Discussions on literature were accompanied by numerous attractions, including a film review, exhibitions and parties. The star of the event was Soviet cosmonaut Alexei Leonov; to the disappointment of many participants, Stanisław Lem did not attend Eurocon. The guests from the West found themselves under surveillance by the Security Service, but no activities of a political nature were reported during the convention. The communist authorities became involved in organising the event, seeing it as an excellent propaganda tool. Still, the ideological message was overshadowed by the personal contacts and informal atmosphere typical of conventions.

\section{Bibliografia}

Franaszek A., Herbert. Biografia, t. II: Pan Cogito, Kraków 2018.

Majowski M., Polska Ludowa zaprasza. Polityka turystyczna w czasach Edwarda Gierka, Warszawa 2008.

Materiały z Międzynarodowego Spotkania Pisarzy - Twórców Literatury Fantastycznonaukowej, red. J. Kaczmarek, B. Kledzik, Poznań 1974.

Niewiadowski A., Smuszkiewicz A., Leksykon polskiej literatury fantastycznonaukowej, Poznań 1990.

Orliński W., Lem. Życie nie z tej ziemi, Warszawa 2019.

Pindel T., Historie fandomowe, Wołowiec 2019.

Sedeńko W., Pejzaż z gwiazdami, Stawiguda 2018.

Sowiński P., Turystyka zagraniczna $w$ Polsce $w$ latach 1956-1980, „Dzieje Najnowsze” 2002, nr 1, s. $135-144$.

Szulc P., Mirosław Hermaszewski - kosmiczna ikona propagandy sukcesu, „Dzieje Najnowsze” 2012, nr 4, s. 45-62. 
Wierzchowska A., Wyobraźnia koncesjonowana. Polskie Stowarzyszenie Miłośników Fantastyki 1981-1989, w: Nie (tylko) Partia? Organizacje społeczne w Polsce Ludowej 1944-1989 geneza, funkcjonowanie, znaczenie, red. T. Ruzikowski, Warszawa 2018, s. 351-379.

Wilk H., Od Sputnika do selenonautów. Kosmiczny wyścig w świetle oficjalnej propagandy PRL (1957-1969), w: Yesterday. Studia z historii najnowszej. Ksiega dedykowana prof. Jerzemu Eislerowi w 65. rocznicę urodzin, red. J. Olaszek, Warszawa 2017, s. 375-389.

Aleksandra Wierzchowska - doktorantka w Instytucie Historii Polskiej Akademii Nauk, pracuje w Instytucie Pamięci Narodowej. Zainteresowania badawcze: fandom, historia społeczna PRL. E-mail: aleksandra.wierzchowska@gmail.com.

Aleksandra Wierzchowska - PhD student at the Tadeusz Manteuffel Institute of History of the Polish Academy of Sciences, working at the Institute of National Remembrance. Research interests: fandom, social history of the Polish People's Republic. E-mail: aleksandra.wierzchowska@gmail.com. 